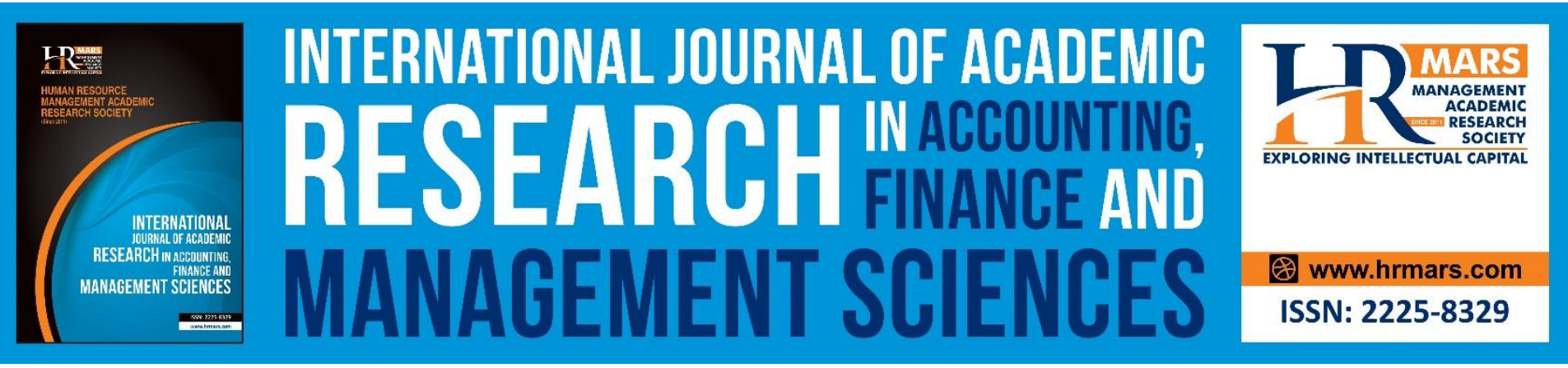

\title{
Conceptual Review on the Role of Self Efficacy in influencing Work Life Balance of Telecommuters
}

\author{
Khartikka Chandrasekaran, Fatimah Wati Halim, Wan Sharazad Wan \\ Sulaiman, Nurul-Azza Abdullah
}

To Link this Article: http://dx.doi.org/10.6007/IJARAFMS/v11-i3/10809 DOI:10.6007/IJARAFMS /v11-i3/10809

Received: 19 June 2021, Revised: 21 July 2021, Accepted: 30 July 2021

Published Online: 20 August 2021

In-Text Citation: (Chandrasekaran et al., 2011)

To Cite this Article: Chandrasekaran, K., Halim, F. Wati, Sulaiman, W. S. W., \& Abdullah, N.-A. (2011). Conceptual Review on the Role of Self Efficacy in influencing Work Life Balance of Telecommuters. International Journal of Academic Research in Accounting Finance and Management Sciences, 11(3), 94-107.

Copyright: (C) 2021 The Author(s)

Published by Human Resource Management Academic Research Society (www.hrmars.com)

This article is published under the Creative Commons Attribution (CC BY 4.0) license. Anyone may reproduce, distribute, translate and create derivative works of this article (for both commercial and non-commercial purposes), subject to full attribution to the original publication and authors. The full terms of this license may be seen at: $\underline{\text { http://creativecommons.org/licences/by/4.0/legalcode }}$

Vol. 11, No. 3, 2021, Pg. 94 - 107

http://hrmars.com/index.php/pages/detail/IJARAFMS JOURNAL HOMEPAGE

Full Terms \& Conditions of access and use can be found at http://hrmars.com/index.php/pages/detail/publication-ethics 


\title{
Conceptual Review on the Role of Self Efficacy in influencing Work Life Balance of Telecommuters
}

\section{Khartikka Chandrasekaran ${ }^{\mathrm{a}}$, Fatimah Wati Halim ${ }^{\mathrm{b}}$, Wan Sharazad Wan Sulaimanc, Nurul-Azza Abdullah ${ }^{d}$}

aTunku Abdul Rahman University College,Jalan Genting Kelang, Setapak,53300 Kuala Lumpur,P.O. Box 10979, 50932 Kuala Lumpur, Malaysia, b,c,dPsychology Program, Centre for Research in Psychology and Human Well-being, Faculty of Social Sciences and Humanities, Faculty of Social Science \& Humanities, Universiti Kebangsaan Malaysia, Malaysia Email: atisha@ukm.edu.my

\begin{abstract}
Background: Work-from-home (WFH) has become a more common alternative work arrangement to reduce the risk of COVID-19 infection amidst pandemic. Although WFH was a fantasy for many employees prior to the pandemic and offered some advantages, it has proven to be a difficult work arrangement for most telecommuters during this pandemic situation. Objective: Considering the challenges experienced by telecommuters and to improve their well-being, this article reviews some of the challenges experienced by telecommuters in a pandemic situation. The impact of personal resources such as self-efficacy and flow on Work Life Balance (WLB) were also reviewed. Besides that, influential WLB theories were also reviewed. Design: Relevant work life balance and well-being articles published before and after the pandemic between 1990 to 2021 were identified for review using appropriate keywords. Results: WFH has many benefits, but when implemented in a forced manner in a pandemic situation, employees experienced blurred boundaries, leading to poor WLB. Resources such as self-efficacy and flow can help telecommuters deal with this unprecedented crisis in a more regulated, calm and positive manner. Review of theories and literatures contributed to the development of a Crisis Induced Resources and Balance/Conflict Framework. Conclusions: Pandemic situation has worsened work life balance of telecommuters who struggle in creating and maintaining the boundary between work and home. However, telecommuters can learn to regulate themselves more effectively and manage their boundary with others. Government and companies can communicate better WFH guidelines, policies and also show support to their workers during this crisis.
\end{abstract}

Keywords: Work-From Home, Telecommuters, Work Life Balance, Work Life Conflict, Flow, Self -Efficacy, Conservation of Resources.

\section{Introduction}

Governments and corporations in most countries have encouraged (and in some cases mandated) individuals to work from home to minimise the spread of the COVID-19 virus and flatten the curve. 
INTERNATIONAL JOURNAL OF ACADEMIC RESEARCH IN ACCOUNTING, FINANCE AND MANAGEMENT SCIENCES

Vol. 11, No. 3, 2021, E-ISSN: 2225-8329 @ 2021 HRMARS

Hence, Work-From Home (WFH) has become an increasingly pervasive alternative work arrangement to minimise the risk of COVID-19 infection amidst pandemic. According to Ramachandran (2020), working from home has many benefits. Flexibility, increased productivity, no commute, and more quality time with loved ones are just a few of the advantages of working from home. People who work from home consistently report higher levels of job satisfaction and motivation (Binder \& Coad, 2016; Felstead \& Henseke, 2017; Wheatley, 2017). According to a longitudinal nationally representative sample of 30,000 families in the United Kingdom (Reushke,2019), working from home is also positively linked to leisure time satisfaction, meaning that individuals who work from home may dedicate more time to leisure.

Although WFH has many benefits and was an idealised scenario for many employees before the pandemic, it proves to be a difficult work arrangement for most telecommuters during the pandemic because many organisations and individuals were suffering from negative emotions such as Fear, Uncertainty, and Doubt (FUD). When telecommuters WFH, two domains occupy the same physical space leading to a blurred line between work and nonwork. Thus, telecommuters are more prone to experience poor work life balance (WLB).

Even before the pandemic, achieving work-life balance has grown increasingly complex due to digital integration and remote working scenarios, resulting in an "always on" culture that blurs the line between work and personal life. This phenomenon has inspired several researchers to conduct work-life balance studies (Mensah \& Adjei 2020; Nwagbara 2020; Pattusamy \& Jacob 2017; Ramachandran, 2020; Wolor, Kurnianti, Zahra \& Martono, 2020). This digital integration also has contributed to the development of a more inclusive model of WLB. According to Ramachandran (2020), work-life balance was defined as attaining equilibrium between personal and professional responsibilities. Work-life balance is sometimes confused with Work-Life Conflict (WLC). However, WLC is the polar opposite of work-life balance, as it reduces employee well-being and increases psychological stress (Fotiadis, Abdulrahman, \& Spyridou, 2019). The current WLB model, however, is more inclusive and balances work and nonwork interests. Self-management, time management, stress management, change management, technology management, and leisure management are all part of it. The dynamics of work-life balance have changed due to changes in social requirements, available technologies, and personal expectations (Ramachandran, 2020).

However, concerns on work life balance are not new and can be dated back to the 1930s. According to Wolor et al (2020), work life balance programmes were established in 1930, in which firm policies and regulations allow employees to work effectively and efficiently while also providing flexible time to cope with personal difficulties. However, the term "work-life balance" was only officially coined by the Women's Liberation Movement in the United Kingdom in the 1980s. Women's maternity leave and flexible schedules were promoted in this movement (Raja \& Stein, 2014). Concerns on WLB has been further exacerbated during the pandemic situation since most workers are forced to WFH.

WFH is currently accepted as a viable approach for reducing the risk of COVID-19 infection. However, WFH is not a new concept, and it has been brought to the attention of numerous schools of thought for some years. Nilles first introduced the WFH notion in 1973, calling it "telecommuting" or "telework" (Messenger \& Gschwind, 2016). Over the last four decades, WFH has been referred to by various concepts, including remote work, flexible workplace, telework, telecommuting, and eworking. These terms refer to employees' ability to work in flexible workplaces, particularly at home, by utilising technology to complete work tasks (Gajendran \& Harrison, 2007; Grant, Wallace, Spurgeon, Tramontano, \& Charalampous 2019). Gajendran and Harrison (2007) defined 
INTERNATIONAL JOURNAL OF ACADEMIC RESEARCH IN ACCOUNTING, FINANCE AND MANAGEMENT SCIENCES

Vol. 11, No. 3, 2021, E-ISSN: 2225-8329 ๔ 2021 HRMARS

telecommuting as an alternate work arrangement in which employees execute duties offsite that are traditionally conducted in primary or central workplaces, for at least some portion of their work schedule, using electronic media to engage with others inside and outside the organisation. Telework is further defined by International Labour Organisation as the use of information and communication technologies (ICTs) such as smartphones, tablets, laptops, or desktop computers for work undertaken outside the workplace (ILO, 2020).

The sudden implementation of WFH has contributed to many problems. Many researches were done to study the difficulties or problems arising from this new WFH practice (Mensah \& Adjei, 2020; Pirzadeh \& Lingard, 2021; Ramachandran, 2020). This unexpected widespread adoption of home-based teleworking was unprecedented. As a result, the ability to devise plans to safeguard workers' health and safety was limited (Pirzadeh \& Lingard,2021). There have been numerous mistakes and imbalances as a result of many organisations and individuals not being prepared for the same. Many times, the line between work and nonwork has been crossed. In addition, a lack of leisure and other activities and the current circumstance's Fear, Uncertainty, and Doubt (FUD) have exacerbated the problem (Ramachandran, 2020). In addition, Work-Life Conflict also can escalate due to the blurred line (WLC). Work-life conflict occurs when one domain's responsibilities interfere with another, resulting in a lack of balance. Poor physical health, poor self-reported health, psychological distress, poor mental health, and life dissatisfaction can all be linked to work-life conflict (Mensah \& Adjei, 2020).

Considering the challenges experienced by telecommuters and to improve their well-being, this article reviews the literature on work from home and work life balance by further reviewing some of the challenges experienced by telecommuters in a pandemic situation. Identification of critical resources such as self-efficacy and flow influencing WLB will also be reviewed. An individual's sense of self-efficacy can play a significant role in regulating himself or herself in approaching specific goals and tackling difficult situations. On the other hand, flow explores a happy state of mind called flow, the feeling of complete engagement in a creative or playful activity." During flow, people typically experience deep enjoyment, creativity and a total involvement with life (Bakker \& Van Woerkom, 2017; Csikszentmihalyi, 1990) Flow is more likely to happen when people see a balance between the challenge of a situation and their skills to deal with it (Bakker \& van Woerkom, 2017). Besides discussing telecommuters' challenges and critical resources such as self-efficacy and flow, relevant theories related to this topic will also be reviewed from selected journal articles. Hence, this paper summarises what is known, identifies conceptual gaps, and offers vital insight and recommendations for improving telecommuters' work-life balance.

\section{Methods}

Relevant articles published between 1990 to 2021 were identified for review using keywords such as work life balance, work from home, telecommuters, self-efficacy, flow, theories of WLB and many more. Inclusion criteria for review articles are any work life balance and well-being articles in relation to the topic of review. Articles before and after pandemics are also included in this review due to limited articles discussing certain variables in a new norm, WFH, in a pandemic situation. Some wellbeing articles are also considered for inclusion since WLB and well-being are interrelated constructs. According to Kashyap, Joseph, \& Deshmukh (2016), well-being, in general, is seen as a life well lived. It is a broader concept which refers to overall individual's life both on and off the job (Kashyap et al., 2016). Hoffmann-Burdzińska \& Rutkowska (2015) have concluded that work-life balance is related to an individual's psychological well-being and overall sense of harmony in life. Hoffmann-Burdzinska 
INTERNATIONAL JOURNAL OF ACADEMIC RESEARCH IN ACCOUNTING, FINANCE AND

MANAGEMENT SCIENCES

Vol. 11, No. 3, 2021, E-ISSN: 2225-8329 ๑ 2021 HRMARS

\& Rutkowska (2015) highlighted work-life balance issue as a factor influencing well-being. Organisations can be significant sources of employees' well-being. The interrelatedness between work life balance, and well-being is further supported by Fotiadis (2019), who claims the ability to balance work and personal activities helps employees improve the quality of their work well-being. Hence, this review has included some well-being articles too.

\section{Results}

\section{Challenges of WFH}

Many current researches have highlighted the challenges experienced by telecommuters during pandemic situation (Allen, Merlo, Lawrence, Slutsky \& Gray, 2021; Bhumika, 2020; Carillo, CachatRosset, Marsan, Saba \& Klarsfeld, 2021; Lagarde, 2020). According to Carillo, et al., (2021), in comparison to telework performed in a traditional setting, telework prompted by a pandemic has unique characteristics. The freedom of location and working time that telework is designed to provide, is no longer allowed in the covid-19 context. Home confinement is imposed, teleworking becomes a full-time requirement, and teleworkers frequently face aggravated professional and personal issues. In addition, telework has become mandatory with no employee agreement, become full-time mode of working, with no time for preparation for teleworkers, managers, organisations, and has the potential for lack of teleworking equipment. Furthermore, with the availability of computers and mobile devices at home, employees are finding it difficult to detach from work (Lagarde, 2020). Palumbo, Manna and Cavallone (2021) study implies due to the blurring of the lines between work and everyday life, home-based telecommuting may cause work-to-life and life-to-work problems swiftly and effectively.

Allen et al (2021); Bhumika (2020) used boundary theory to prove working from home was quite challenging for most employees. Whether they were residing single or with family, they had to participate in some home duties. During the lockdown, balancing job and family obligations was a difficult task for everyone who worked. According to boundary theory, people construct and maintain physical, temporal, and psychological borders around them, in order to simplify their functioning in the environment around them (Bhumika, 2020; Allen et al, 2021). According to Allen et al (2021), employees with lower segmentation preferences were more likely to gain from shifting to WFH during COVID-19. People who prefer segmentation, on the other hand, are more likely to have negative changes in their work-family interactions. Even those who favour integration may find the novelty of complete overlap difficult to accept, but those who prefer segmentation will face the most difficulty in balancing work and nonwork (Allen et al., 2021).

In addition, employees from Asian countries also experience challenges of WFH. Vyas \& Butakhieo (2020), reported Hong Kong's unique working environment makes WFH less favourable for workers, with workers unable to distinguish between personal and professional settings. According to the survey, "employees 35 years and older had to juggle between home and work commitments at the same time," with one possible reason being that people in this region tend to live in multigenerational households, which also means they have less space than their western counterparts, resulting in many distractions and an imbalance between work and home life (Vyas \& Butakhieo 2020). Teo (2020) reveals WFH is seen to increase the workers' stress in Singapore, even more compared to COVID-19 front-line worker. Detrimental effects of working from home is further supported by an Indonesian study. Because employees are still accustomed to having fixed working hours, they are unable to divide their time between work and home life (Irawanto, Novianti \& Roz, 2021). 
INTERNATIONAL JOURNAL OF ACADEMIC RESEARCH IN ACCOUNTING, FINANCE AND MANAGEMENT SCIENCES

Vol. 11, No. 3, 2021, E-ISSN: 2225-8329 @ 2021 HRMARS

Telecommuters also can be distracted at home due to expectations from employees and family members thus leading to blurred boundary between work from home. Because of the telecommuter's ready availability, family members may expect a piece of the telecommuter's time during working hours (Kossek, Thompson, \& Lautsch, 2015). According to Hilbrecht et al. (2013), telecommuters appreciate the privacy, anonymity, and flexibility of working from home; but, the pressure to please employers, family members, and oneself can throw work and life off balance. (Miller 2017). Grant, Wallace and Spurgeon (2013) discovered that the lines between work and family life were blurred which could lead to overwork and a reduction in WLB. Grant et al. (2019) discovered that e-workers struggle to regulate the boundaries between working and non-working time, resulting in an overworked propensity. Employees may be distracted when working at home by the presence of young children or family members, and the blurred lines between work and family life can lead to overwork (Grant et al. 2019). Similarly, according to a survey conducted by the Japanese Ministry of Health and Welfare (MHLW, 2014), 43.5 percent of respondents find it "difficult to draw a line between work and family life." Similar results were obtained in the United States, Argentina, Brazil, and India (ILO, 2017).

However, there are also researches which have shown that WLB can be enhanced by working from home. Grant et al (2013) mentioned e-working improves WLB because e-workers are able to blend work and non-work life. In a 2011, Ipsos special report on telecommuting among US employees, 77 percent of respondents 'agreed' or 'strongly agreed' that employees who telecommute are better able to strike a balance between work and family. However, 70 percent of respondents in this poll said that technology has caused a blurring of boundaries because it has brought work into their personal lives, and 48 percent said that telecommuting creates more work-family conflicts. According to a nationwide research in Brazil, 98 percent of call centre agents who work from home reported a better quality of life, including a better quality of family life, owing to the time saved on commuting (93 percent) and having more time for their families (91 percent ) (ILO, 2017). Furthermore, a longitudinal nationally representative sample of 30,000 families in the United Kingdom discovered that homeworking is positively connected to leisure time satisfaction, implying that those who work from home can devote more time to leisure activities (Aczel, Kovacs, Van der Lippe \& Szaszi, 2021).

\section{Self-Efficacy \& WLB}

Many researches' have linked self-efficacy and well-being, however most of the researches were carried out before pandemic. A study by Halim, Zainal, Mastor (2016) also proves the importance of self-efficacy factors as mediating factors in the influence of Personality and Job Performance Malaysian Public Administrator Officers, but not among telecommuters. There are not many researches done on the relationship between self-efficacy of telecommuters and their work life balance during pandemic. However, there are some researches done on the relationship between self-efficacy and work life balance before the pandemic. Sumitha Wiesenfeld, \& Garud (2003) research was not conducted during pandemic, but it still manages to provide some indirect insight into the relationship between telecommuters self-efficacy and work adjustment which can be associated with WLB. The results of their survey show that telecommuters' self-efficacy is linked to both employees' behavioural strategies (i.e., structuring behaviours) and job outcomes (i.e., telecommuter adjustment) (Sumitha et al., 2003). This study asserts, telecommuters with better personal resource such as self-efficacy are able to survive difficulties and uncertainties in life. (Sumitha et al. 2003). Similar results linking self-efficacy and ability to survive in difficult 
INTERNATIONAL JOURNAL OF ACADEMIC RESEARCH IN ACCOUNTING, FINANCE AND MANAGEMENT SCIENCES

Vol. 11, No. 3, 2021, E-ISSN: 2225-8329 @ 2021 HRMARS

circumstances were also revealed by other researchers. Tandon (2017) highlighted people who are self-assured in their abilities see difficult professions as challenges to overcome rather than dangers to avoid. A successful outlook fosters intrinsic interest and thorough engrossment in activities. They set challenging goals for themselves and stick to them with zeal. They continue to amplify and sustain their activities (Tandon, 2017).

\section{Flow, Self-Efficacy \& Well-Being}

Self- efficacy can influence individual's state of flow. According to Mesurado, Richaud, and Mateo (2016), when college students have a higher sense of computer self-efficacy, their flow experience also increases. Bakker \& Van Woerkom (2017), highlights self-efficacy beliefs were both predictors and consequences of flow, thus implying that personal resource has a reciprocal relationship with flow. In addition, a study by Scrima, Civilleri, and Salerno (2016) found that self-efficacy, specifically occupational self-efficacy, mediated the relationship between job insecurity, work engagement, job satisfaction, and health in private and public sector employees. The findings suggest that occupational self-efficacy sources should be considered when planning interventions (Scrima et al., 2016).

There were also many researches linking flow, self-efficacy and well-being (Bakker \& Van Woerkom, 2017; Rankin, Walsh, \& Sweeny, 2018; Zito, Cortese \& Colombo, 2019). Bakker and Van Woerkom (2017) reviewed research on flow at work, and claimed that, rather than reacting passively to their work environment, people can control their own flow experience using self-determination theory. They also assert that factors within the organisational context, such as human resource practices and leadership, as well as personal resources, such as self-efficacy and optimism, moderate the effectiveness of these strategies. According to Zito et al. (2019), flow at work was shown to be favourably connected with job resources, and flow at work was found to be positively associated with happy feelings. The link between these characteristics and happiness/discomfort at work emphasises the necessity of encouraging flow at work and supporting employment resources that foster happy work experiences. Rankin et al. (2018) suggest flow is excellent for enhancing emotional well-being during stressful situations of uncertainty, such as waiting for BAR exam results. Their findings suggest that flow may be an antidote to anxiety caused by uncertainty related distress.

\section{Theories of Work Life Balance}

Reviews of articles highlights many WLB theories explaining work life balance and it's relationships with self-efficacy and flow. Some researchers have discussed and used certain theories of WLB in their research before the pandemic (Bakker \& Van Woerkom, 2017; Lagarde, 2020; Miller, 2017; Tandon,2017). Bakker Integrates flow and self-determination theories (Bakker \& van Woerkom, 2017). Lagarde (2020) used Adaptive structuration theory \& Sociotechnical System Theory and Miller (2017) used Maslow's (aesthetic need) \& Herzberg's (hygiene) theories. Tandon (2017) studying on relationship between self-efficacy and flow at work used Social Cognitive Theory, Social Learning Theory and Social Concept.

However, there were a few other researchers who have linked their research to current pandemic scenario and provide more meaningful theories which are relevant to the pandemic situation (Allen, Merlo, Lawrence, Slutsky \& Gray, 2021; Bhumika, 2020; \& Carillo, 2020). Allen et al. (2021) and Bhumika (2020) used Boundary Theory to explain work life balance of telecommuters in a pandemic situation. Carillo (2020) on the other hand has introduced Crisis induced Telework 
INTERNATIONAL JOURNAL OF ACADEMIC RESEARCH IN ACCOUNTING, FINANCE AND MANAGEMENT SCIENCES

Vol. 11, No. 3, 2021, E-ISSN: 2225-8329 @ 2021 HRMARS

Adjustment framework, which he formed from the combination of Theory of Work Adjustment (TWA) and the Interactional Model of Individual.

Table 1 below summarises literatures above and key theories of work life balance used before pandemic and during pandemic situation.

\begin{tabular}{|c|c|}
\hline $\begin{array}{l}\text { Before pandemic (Theory/Theories, } \\
\text { researcher. }\end{array}$ & $\begin{array}{l}\text { After pandemic (Theory/ Theories, } \\
\text { researcher) }\end{array}$ \\
\hline $\begin{array}{l}\text { 1. Maslow (aesthetic need) \& Herzberg } \\
\text { (hygiene) (Miller, 2017). } \\
\text { 2. Adaptive structuration theory \& } \\
\text { Sociotechnical System Theory } \\
\text { (Lagarde, 2020). } \\
\text { 3. Social Cognitive Theory, Social } \\
\text { Learning Theory, Social Concept } \\
\text { Theory (Tandon, 2017). } \\
\text { 4. Integration of flow and self- } \\
\text { determination theories (Bakker \& } \\
\text { van Woerkom, 2017). }\end{array}$ & $\begin{array}{l}\text { 1. Boundary Theory (Bhumika,2020). } \\
\text { 2. Boundary theory (Allen, Merlo, } \\
\text { Lawrence, Slutsky \& Gray, 2021). } \\
\text { 3. Crisis-induced Telework Adjustment } \\
\text { framework (theoretical foundation } \\
\text { is from Theory of Work Adjustment } \\
\text { (TWA) (Dawis \& Lofquist, 1984) and } \\
\text { the Interactional Model of } \\
\text { Individual Adjustment } \\
\text { (Carillo,2020). }\end{array}$ \\
\hline
\end{tabular}

Table 1 : Summary of relevant literatures and theory of WLB used before and after pandemic.

The major conceptual frameworks pertaining to work and life domains, however are actually wider. Spill-over, compensation, work-family conflict, resource drain, enrichment, congruence, segmentation, integration, role theories, border theory, boundary management theory, gender inequality theory, work-life management theory and ecological theories are some of the common theories covered in WLB studies (Gayathri,2016). Conservation of Resources Theory is without a doubt is one of the most significant theories for understanding human stress and happiness. The COR hypothesis explains how people react to stresses in their environment and how those encounters affect their well-being. The first assumption of COR theory is that people try to get, keep, and guard resources, and that stress occurs when they are on the verge of losing, or have already lost, those resources. COR theory's second important premise is that resources can generate new resources. This practise is known as "resource caravans," which refers to the fact that resources are delivered in bundles. When there are no stressors, people try to get more resources (Ten Brummelhuis, \& Bakker, 2012).

\section{Conceptual Framework}

Inspired by COR theory and Crisis Induced Work proposed by Carillo (2020) (please refer to table 1 above), this article based on earlier discussion of reviews suggests a Crisis Induced Resources and Balance framework as in figure 1 below. The major theory contributing to the formulation of this framework is COR theory which is most influential in explaining the contribution of self-efficacy and flow in promoting work life balance. COR is a stress theory of WLB which could be more relevant to be applied in a pandemic situation. 


\section{CRISIS CONTEXT : PANDEMIC SITUATION}

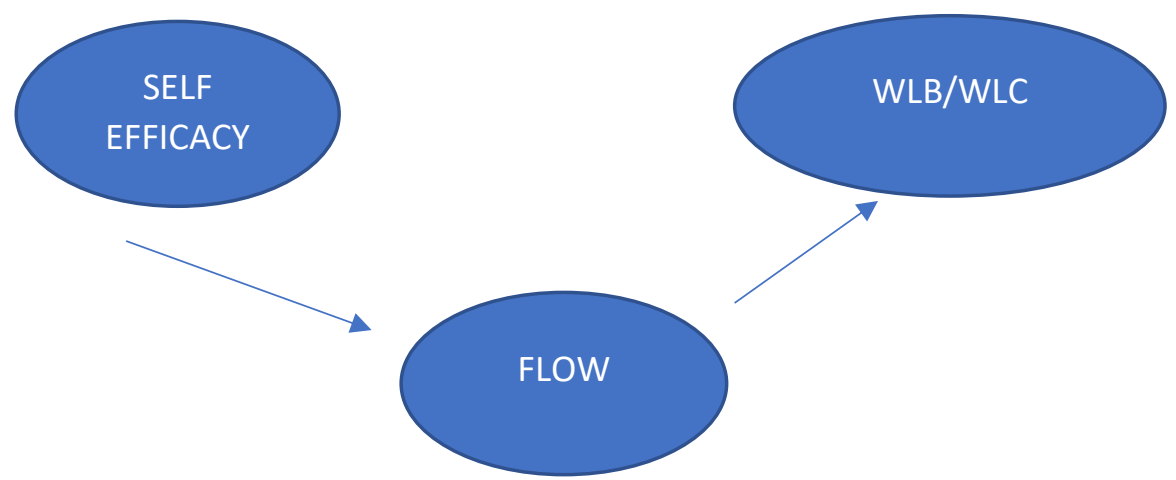

Figure 1 : Conceptual framework : Crisis Induced Resources and Balance/Conflict Framework.

This framework can explain individual's behaviour in reacting to stress in a difficult environment which is associated with WFH during pandemic. Whether or not an individual experiences WLB or WLC is very much dependent on key resources such as self-efficacy and flow. Based on COR Theory, the common assumption will be, people will try their best to obtain, cultivate and protect to their valuable resources which are self-efficacy and flow. Depletion of this resources may lead to stress and work life conflict. The above framework also illustrates resource caravan where possession of self-efficacy skills can generate experiences of flow which is supported by most research in review. When there are no strains, such as work family conflict and pandemic situation, people will try to accumulate more self-efficacy and flow resources (Farradinnah et al., 2020). Hence this framework suggests, accumulation of these key resources can help people to feel more selfregulated, stable, calm, positive and happy even during a pandemic situation.

\section{Discussions}

Although there has been an increase in study on work-life balance and tools that help improve WLB over the last decade, there is still considerable work to be done to understand, assess, and encourage WLB of telecommuters in a pandemic situation. The research's contradicting findings review, illustrates working from home has both advantages and drawbacks. It has many benefits, but when it's implemented in a forced manner in an unprecedented situation such as during pandemic, employees were unprepared and experience negative emotions such as fear, uncertainty and doubt. This situation could have escalated further by employees' lack of skill in using technology and this situation can affect worker's efficacy in managing their time, work and life which leads to poor balance. Social distancing could also further increase this problem since employees might just suppress their difficulties within themselves without sharing their problems in attaining work life balance with others. This could also lead to poor perception of social support (Sulaiman et al., 2020). Hence, WFH itself can be beneficial but it has to be done with proper planning and policy implementation to avoid problems leading to poor work life balance.

Most research were able to show positive correlation between resources such as self-efficacy, flow and work life balance. Self-efficacy is, without a doubt, the most researched personal resource that has been linked to flow and work-life balance. This happens because efficacy beliefs encourage people to predict positive and bad consequences from various endeavours and to devise a strategy for achieving desired outcomes. Flow on the other hand can induce happy feeling and act as another 
INTERNATIONAL JOURNAL OF ACADEMIC RESEARCH IN ACCOUNTING, FINANCE AND MANAGEMENT SCIENCES

Vol. 11, No. 3, 2021, E-ISSN: 2225-8329 ๑ 2021 HRMARS

resource which helps to improve one's well-being especially in difficult time. Hence, by focusing on positive psychology to cope with life challenges such as Covid-19, people can foster and strengthen key personal resources (Abu Bakar, 2020). Self-efficacy and flow can serve as coping mechanism in helping people to cope with difficulties. Those with self-efficacy can regulate themselves better in managing their life and work and flow experiences can help to boost positive thoughts and emotions during pandemic situation. Work-life balance, especially during uncertain times like COVID-19, is essential to employees' growth and personal happiness and company retention.

Review of relevant theories affecting work life balance contributed to the development of Crisis Induced Resources and Balance framework. Based on this framework, people can acquire important valuable resources to help them survive in this difficult situation. It's very important to stay positive and cheerful during pandemic situation. Recognition of these key resources can help people to emanate positive energies, improve individual's resilience and mental strengths.

\section{Conclusion}

Difficulties experienced by telecommuters while WFH in a pandemic situation can be attributed to a forced and precipitous implementation of WFH without clear policy and guideline. This sudden intervention has also failed to prepare telecommuters to deal with the challenges of working from home. Environmental strain such as dealing with a pandemic situation has made the situation worse. Literatures also imply, while working from home during the lockdown, employees could have struggled in creating and maintaining boundaries due to which they might have experienced some difficulties in maintaining WLB.

However, exploration of the current situation in this review, could provide unique insight into how to work from home effectively, and could serve as a major pathway to change the current way of working from home to a more flexible practice. Telecommuters themselves can make an effort to improve their difficulties by managing boundaries. They should take initiative to set boundary between personal workspace and professional duties, away from personal distractions and still liaise with managers. They can also set and follow a proper schedule which clearly segregates the time they are suppose to work and interact with family members. They can be more mindful on their time spent on certain activities and handle distractions better. Besides that, they can be more assertive in communicating their difficulties in setting boundary to those distracting them. Most importantly, they need to learn to be more efficacious and create flow experiences. Hence, these resources can also provide employees with job crafting experiences. Through job crafting, employees can be proactive and utilise opportunities to customize their jobs by actively changing their tasks and interactions with others at work.

However, employees' effort to be more in control of the situation and make appropriate changes to their work arrangement might not be effective, if they lack support or resources from their employer or government (Abdul Aziz, 2018). Government and employers also need to provide important resources for employees to work from home (Abdullah et al., 2018). They can arrange a more conducive and flexible telework arrangements, with clear WFH guidelines adhering to proper Standard Operating Procedures (SOP). Hence, this guidelines, can help to prevent employees from being connected 24/7 with work commitment via technology. Most importantly, proper guidance and training should be given to employees on WFH practices. Employees who are quite poor in using technology can be sent for training without demeaning them. It's very crucial for management to show support and understanding towards telecommuters' challenges. Management can provide counselling services to telecommuters who are struggling with the challenges of WFH. Besides that, 
INTERNATIONAL JOURNAL OF ACADEMIC RESEARCH IN ACCOUNTING, FINANCE AND

MANAGEMENT SCIENCES

Vol. 11, No. 3, 2021, E-ISSN: 2225-8329 @ 2021 HRMARS

companies can also formulate family friendly policies to foster social support during pandemic situation.

\section{Limitations}

There are some limitations in this review which must be acknowledged to facilitate future research efforts. The nature of this research itself which is a conceptual review, might not be sufficient to provide a meaningful practical application of improvement of telecommuters' balance. Hence future researchers can also consider utilising or combining other qualitative and quantitative research methods such survey methods, experimental methods, interview, focus group and observations.

In the current review, the inclusion criteria is not stringent enough since the articles reflecting the relationship of chosen variables with other variables in pandemic situations might not be sufficient enough in the current context, to reflect the true influence of the variable in a pandemic situation. Hence future researchers can also consider including more inclusive articles. In future there will be more articles discussing the new norm WFH in a pandemic situation, thus the inclusion criteria for chosen literatures in future can be more stringent in terms of only including telecommuting or utilisation of key resources in a pandemic situation.

The current review also failed to explore other meaningful variables such as culture and gender differences. Individual differences can also influence the variables relationship with intended outcome or behaviour. Therefore, future researches can consider including individual differences or traits such as culture, gender, Intelligent Quotient, Emotional Quotient and social background in similar research topic as this.

\section{References}

Aczel, B., Kovacs, M., Van der Lippe, T., \& Szaszi, B. (2021). Researchers working from home: Benefits and challenges. PLOS ONE 16(3). https://doi.org/10.1371/journal.pone.0249127

Allen, T. D., Merlo, K., Lawrence, R. C., Slutsky, J., \& Gray, C. E. (2021). Boundary Management and Work-Nonwork Balance While Working from Home. Applied Psychology 70(1), 60-84. https://doi.org/10.1111/apps.12300

Abdullah, A. B., Halim, F. W., \& Abdullah, N. A. (2018). Ethical leadership and its relationship with organizational performance: organizational trust as a mediator. International Journal of Creative Research Thoughts. 6(1): 452-459.

Aziz, S. F. A. (2018). Bagaimana organisasi boleh memotivasikan pekerja untuk belajar dalam latihan: persepsi ahli akademik. Akademika: 88: 5-20.

Bakker, A. B., \& Van Woerkom, M. (2017). Flow at Work: a Self-Determination Perspective. Occupational Health Science 1(1-2), 47-65. https://doi.org/10.1007/s41542-017-0003-3.

Bakar, M. R. A., \& Halim, F. W. (2020). Kesihatan dan Kesejahteraan di Tempat kerja.

Bhumika, B. (2020). Challenges for work-life balance during COVID-19 induced nationwide lockdown: exploring gender difference in emotional exhaustion in the Indian setting. Gender in Management. 35(7-8), 705-718. https://doi.org/10.1108/GM-06-2020- 0163

Binder, M., \& Coad, A. (2016). How Satisfied are the Self-Employed? A Life Domain View. Journal of Happiness Studies, 17(4), 1409-1433. https://doi.org/10.1007/S10902-015-9650-8

Carillo, K., Cachat-Rosset, G., Marsan, J., Saba, T., \& Klarsfeld, A. (2021). Adjusting to epidemicinduced telework: empirical insights from teleworkers in France. European Journal of Information Systems 30(1), 69-88. https://doi.org/10.1080/0960085X.2020.1829512

Csikszentmihalyi, M. (1990). Flow : The psychology of optimal experience. New York. Harper \& Row. 
INTERNATIONAL JOURNAL OF ACADEMIC RESEARCH IN ACCOUNTING, FINANCE AND

MANAGEMENT SCIENCES

Vol. 11, No. 3, 2021, E-ISSN: 2225-8329 @ 2021 HRMARS

Eurofound and the International Labour Office. (2017). Working anytime, anywhere: The effects on the world of work, Publications Office of the European Union, Luxembourg, and the International Labour Office, Geneva. Retrieved from

https://www.eurofound.europa.eu/publications/report/2017/working-anytime-anywherethe-effects-on-the-world-of-work

Farradinna, S., Halim, F. W., Sulaiman, W. S. W. (2020). How does the impact of work-family enrichment on work-family conflict and psychological well- being among academics' female in Indonesia?. Test Engineering and Management Journal 83 :26874-26900.

Felstead, A., \& Henseke, G. (2017) Assessing the growth of remote working and its consequences for effort, well-being and work-life balance. New Technology, Work and Employment 32(3): 195212. https://doi.org/10.1111/ntwe.12097

Fotiadis, A., Abdulrahman, K., \& Spyridou, A. ( 2019). The mediating roles of psychological autonomy, competence and relatedness on work-life balance and well-being. Frontiers in Psychology 10(MAY), 1-7. https://doi.org/10.3389/fpsyg.2019.01267

Gajendran, R. S., \& Harrison, D. A. (2007). "The Good, the Bad, and the Unknown About Telecommuting: Meta-Analysis of Psychological Mediators and Individual Consequences."

The Journal of Applied Psychology 92 (6), 1524-1541. https://doi.org/10.1037/0021-

Gayathri, P. (2016). Conceptualising Work-life Balance. Research Scholar, Institute for Social and Economic Change, Bangalore 1-15. Retrieved from http://www.isec.ac.in/WP\%20368\%20\%20Gayathri\%20Pradhan\%20-\%20Final.pdf 9010.92.6.1524

Hilbrecht, M., Shaw, S., Johnson, L., \& Andrey, J. (2013). Remixing work, family, and leisure: Teleworkers' experiences of everyday life. New Technology, Work and Employment, 28(2), 130-144. https://doi.org/10.1111/ntwe.12010

Hoffmann-Burdzińska, K., \& Rutkowska, M. (2015). Work Life Balance As a Factor Influencing WellBeing. Journal of Positive Management 6(4),87. http://dx.doi.org/10.12775/JPM.2015.02

ILO. (2020). Teleworking during the Covid-19 Pandemic and beyond. Geneva. International Labour Office. Retrieved from https://www.ilo.org/wcmsp5/groups/public/---ed_protect/--protrav/travail/documents/instructionalmaterial/wcms_751232.pdf

Irawanto, D. W., Novianti, K. R., \& Roz, K. (2021). Work from Home : Measuring Satisfaction between Work - Life Balance and Work Stress during the COVID-19 Pandemic in Indonesia. Economies, 9: 96. https://doi.org/10.3390/economies9030096

Lagarde, C. P. (2020). Work-Life Balance: Perceived Differences of Teleworkers and Non-Teleworkers. Dissertations Retrieved from https://apcz.umk.pl/czasopisma/index.php/JPM/article/view/JPM.2015.024

Kashyap, S., Joseph, S., \& Deshmukh, G. K. (2016). Employee Well-Being, Life Satisfaction and the need forWork-Life balance. Journal of Ravishankar University (22): 11-23. Retrieved from https://www.researchgate.net/publication/311322121_Employee_Well-

Being_Life_Satisfaction_and_the_need_for_Work-Life_balance

Mensah, A., \& Adjei, N. K. (2020). Work-life balance and self-reported health among working adults in Europe: A gender and welfare state regime comparative analysis. BMC Public Health 20(1), 1-14. https://doi.org/10.1186/s12889-020-09139-w

Messenger, J. C., \& Gschwind, L. (2016). "Three Generations of Telework: New ICTs and the (r)Evolution from Home Office to Virtual Office." New Technology, Work and

Employment. 31 (3), 195-208. https://doi.org/10.1111/ntwe.12073

Mesurado, B., Richaud, C. M., \& José Mateo, N. (2016). Engagement, flow, self-efficacy, and Eustress 
INTERNATIONAL JOURNAL OF ACADEMIC RESEARCH IN ACCOUNTING, FINANCE AND

MANAGEMENT SCIENCES

Vol. 11, No. 3, 2021, E-ISSN: 2225-8329 @ 2021 HRMARS

of University Students: A cross-national comparison between the Philippines and Argentina. Journal of Psychology, Interdisciplinary and Applied 150(3): 281-299.

Miller, T. (2016). How telecommuters balance work and their personal lives. Ph.D. Thesis, Baker College, MIS Baker College Flint, Michigan. Retrieved from https://www.researchgate.net/publication/316107871_

Nwagbara, U. (2020), "Institutions and organisational work-life balance (WLB) policies and practices: Exploring the challenges faced by Nigerian female workers", Journal of Work-Applied Management, 12 (1). pp. 42-54. https://doi.org/10.1108/JWAM-112019-0035

Palumbo, R., Manna, R., \& Cavallone, M. (2021), "Beware of side effects on quality! Investigating the implications of home working on work-life balance in educational services", The TQM Journal, Vol. 33 No. 4, pp. 915-929. https://doi.org/10.1108/TQM-05-2020-0120

Pattusamy, M., \& Jacob, J. (2017). A Test of Greenhaus and Allen (2011) Model on WorkFamily Balance. Current Psychology 36(2), 193-202. https://doi.org/10.1007/s12144-015-94004

Pirzadeh, P., \& Lingard, H. (2021). Working from Home during the COVID-19 Pandemic: Health and Well-Being of Project-Based Construction Workers. Journal of Construction Engineering and Management 147(6). https://doi.org/10.1061/(ASCE)CO.1943-7862.0002102

Raghuram, S., Wiesenfeld, B., \& Garud, R. (2003). Technology enabled work: The role of selfefficacy in determining telecommuter adjustment and structuring behavior. Journal of Vocational Behavior 63(2),180-198. https://doi.org/10.1016/S0001- 8791(03)00040-

XGet rights and content ...

Ramachandran, R. ( 2020). Work Life Balance During Lockdown. SSRN Electronic Journal . http://dx.doi.org/10.2139/ssrn.3717081

Reuschke D.(2019).The subjective well-being of homeworkers across life domains. Environ Plan Econ Space. 51(6):1326-49. https://doi.org/10.1177\%2F0308518X19842583

Sulaiman, W. S. W., Kamaludin, M. R., Zamani, Z. A., Khairudin, R., Halim, F. W. (2020). Social support as a mediator in the relationship between job insecurity and psychological well-being among employees in public and private sectors. Jurnal Psikologi Malaysia 34 : 195-205.

Tandon, T. (2017). A Study on Relationship Between Self Efficacy and Flow at Work Among Young Adults. International Journal of Indian Psychology, 4( 4), 88-100. Retrieved from https://ijip.in/articles/a-study-on-relationship-between-self-efficacy-and-flw-at-work-amongyoung-adults/

Ten Brummelhuis, L. L., \& Bakker, A. B. (2012). A resource perspective on the work-home interface: The work-home resources model. American Psychologist 67(7), 545-556. DOI:10.1037/a0027974. https://psycnet.apa.org/doi/10.1037/a0027974

Teo, J. ( 2020). "More Working from Home Feel Stressed Than Those on Covid-19 Front Line: Survey." Accessed 19 Aug 2020. https://www.straitstimes.com/singapore/health/moreworkfrom-homers-feel-stressed-than-front-line-workers-singapore-survey-on

Vyas, L., \& Butakhieo, N. (2020). The impact of working from home during COVID-19 on work and life domains: an exploratory study on Hong Kong. Policy Design and Practice 4(1), 1-18. https://doi.org/10.1080/25741292.2020.1863560.

Wheatley, D. (2017). Employee satisfaction and use of flexible working arrangement. Work, Employment and Society, 31(4):567-585. https://doi.org/10.1177\%2F0950017016631447

Wolor, C. W., Kurnianti, D., Zahra, S. F., \& Martono, S. (2020). The importance of work-life balance on employee performance millennial generation in Indonesia. Journal of Critical Reviews 
INTERNATIONAL JOURNAL OF ACADEMIC RESEARCH IN ACCOUNTING, FINANCE AND

MANAGEMENT SCIENCES

Vol. 11, No. 3, 2021, E-ISSN: 2225-8329 @ 2021 HRMARS

7(9),1103-1108. http://dx.doi.org/10.31838/jcr.07.09.203

Zito, M., Cortese, C. G., \& Colombo, L. (2019). The Role of Resources and Flow at Work in Well-Being. SAGE Open 9(2). https://doi.org/10.1177\%2F2158244019849732 